\title{
Evaluasi Iklim Kerja di Bagian Produksi pada Industri Keramik di Wilayah Gresik
}

\author{
Merry Sunaryo ${ }^{1}$, Moch. Sahri ${ }^{2}$ \\ ${ }^{1,2)}$ Program Studi Keselamatan dan Kesehatan Kerja, Fakultas Kesehatan, \\ Universitas Nahdlatul Ulama Surabaya, \\ E-mail:1'merry@unusa.ac.id, ${ }^{2}$ sahrimoses@unusa.ac.id
}

\begin{abstract}
ABSTRAK
Iklim kerja panas bermula dari munculnya energi panas yang berasal dari sumber panas yang dipancarkan langsung atau melalui perantara dan masuk ke lingkungan kerja, dan menjadi tekanan panas sebagai beban tambahan bagi tenaga kerja. Hal tersebut dapat memperburuk kondisi kesehatan dan stamina tenaga kerja bila ditambah dengan beban kerja fisik yang berat. Industri keramik merupakan memerlukan teknik-teknik yang khusus dan unik seperti pembakaran. Iklim kerja panas sendri dapat mempengaruhi kondisi fisik dan mental pekerja. Dampak yang sering terjadi pada pekerja akibat klim kerja panas yaitu kelelahan dan dehidrasi. Tujuan dari penelitian ini adalah untuk Menganalisis kondisi iklim kerja pada lingkungan kerja dan mengevaluasi iklim kerja di bagian produksi, yang nantinya akan dibandingkan dengan nilai ambang batas sehingga dapat dijadikan dasar dalam melakukan tindakan pengendalian dalam upaya pencegahan penyakit akibat kerja pada industri. Oleh sebab itu, perlunya pengendalian iklim kerja baik dalam lingkungannya maupun pekerjanya. Pengendalian tersebut yaitu Pengendalian secara umum seperti Training (pendidikan/latihan), Pengendalian tekanan panas melalui penerapan hygiene. Penelitian ini merupakan penelitian deskriptif, dengan menggunakan rancangan studi cross sectional. Pengukuram iklim kerja yang dilakukan pada 4 perusahaan pada industri keramik di wilayah Gresik dengan 10 titik pengukuran di masing-masing perusahaan, diketahui memiliki hasil yaitu sebagian besar memiliki nilai $I S B B>30^{\circ} \mathrm{C}$. Pengamatan yang telah dilakukan beban kerja pada industri keramik yaitu beban kerja sedang dengan waktu kerja 75\%-100\% dengan 25\% waktu istirahat. Berdasarkan hasil rata-rata 10 titik dari ke empat perusahaan nilai ISBB hasil pengukuran lebih besar dari nilai $N A B$ yang telah di tetapkan, dengan nilai $N A B 28^{\circ} C$.
\end{abstract}

Kata kunci: Iklim Kerja, Industri Keramik, NAB

\begin{abstract}
Hot work climate starts from the emergence of heat energy that comes from a heat source that is emitted directly or through an intermediary and enters the work environment, and becomes a heat pressure as an additional burden on the workforce. This can worsen health conditions and labor stamina when added to the heavy physical workload. The ceramics industry requires special and unique techniques such as combustion. The hot work climate itself can affect the physical and mental condition of workers. The impact that often occurs in workers due to the heat of work is fatigue and dehydration. The purpose of this study is to analyze the conditions of the work climate in the work environment and evaluate the work climate in the production section, which will be compared to the threshold value so that it can be used as a basis for carrying out control measures in an effort to prevent occupational diseases in the industry. This research is a descriptive study, using a cross sectional study design. Measurements of work climate carried out on 4 companies in the ceramics industry in the Gresik region with 10 measurement points in each company, are known to have results, most of which have ISBB values> $30^{\circ} \mathrm{C}$. Observations that have been carried out workloads on the ceramics industry are moderate workloads with a working time of $75 \%-100 \%$ with $25 \%$ rest time. based on the results of an average of 10 points from the four companies the ISBB value of measurement results is greater than the value of the $N A B$ that has been set, with a value of $28^{\circ} C N A B$. Therefore, the need to control the work climate both in its environment and its workers. These controls are general controls such as training (education / training), heat pressure control through the application of hygiene.
\end{abstract}

Keywords: Work Climate, Ceramic Industry, NAB

* Korespondensi Author : Merry Sunaryo. Prodi D-IV Keselamatan dan Kesehatan Kerja, Fakultas Kesehatan, Universitas Nahdlatul Ulama Surabaya, merry@unusa.ac.id, Telp. 085250797537 


\section{PENDAHULUAN}

Tempat kerja yaitu suatu tempat yang di dalamnya terdapat tenaga kerja yang bekerja atau linkungan yang sering dimasuki oleh tenaga kerja untuk urusan suatu usaha serta adanya sumber-sumber bahaya. Jadi dapat dipastikan bahwa di tempat kerja pasti terdapat potensi bahaya yang mengancam keselamatan dan kesehatan pekerja. Keselamatan kerja merupakan salah satu faktor yang harus dilakukan selama bekerja. ${ }^{1}$ Saat ini telah banyak industri yang menggunakan peralatan kerja dan mesin-mesin produksi yang canggih, sehingga dapat diharapkan memberikan hasil produksi yang maksimal. Kemajuan tersebut dapat menimbulkan dampak negatif terhadap lingkungan kerja sekitar, karena semakin meningkat pula jumlah dan jenis bahaya yang ada di tempat kerja maka dapat menyebabkan kecelakaan kerja dan penyakit akibat kerja. Bahaya yang ada ditempat kerja dapat berpengaruh terhadap keselamatan, kesehatan, dan produktivitas tenaga kerja. ${ }^{2}$

Keselamatan dan Kesehatan Kerja (K3) memiliki makna perlindungan bagi tenaga kerja yang merupakan aset penting dan berharga bagi organisasi dari terjadinya kecelakaan kerja (KK) dan penyakit akibat kerja (PAK). ${ }^{3}$ Sehingga diperlukannya lingkungan kerja yang aman, sehat dan nyaman yang mendukung tenaga kerja melaksanakan pekerjaannya dan mencegah terjadinya kecelakaan kerja dan penyakit akibat kerja guna mewujudkan produktivitas kerja yang optimal. $^{4}$

Iklim kerja adalah kombinasi dari suhu udara, kelembapan udara, kecepatan aliran udara dan panas radiasi ${ }^{4}$. Iklim kerja panas bermula dari munculnya energi panas yang berasal dari sumber panas yang dipancarkan langsung atau melalui perantara dan masuk ke lingkungan kerja, dan menjadi tekanan panas sebagai beban tambahan bagi tenaga kerja. ${ }^{5}$ Hal tersebut dapat memperburuk kondisi kesehatan dan stamina tenaga kerja bila ditambah dengan beban kerja fisik yang berat. Sehingga tenaga kerja tersebut akan memerlukan energi yang lebih besar dibandingkan dengan tenaga kerja yang bekerja di lingkungan kerja dengan suhu nyaman yaitu PUSLITBANG Sinergis Asa Professional, Jember $24^{\circ} \mathrm{C}$ sampai dengan $26^{\circ} \mathrm{C}$. Selain itu lingkungan kerja dengan suhu tinggi lebih banyak menimbulkan permasalahan dibandingkan dengan lingkungan kerja dengan suhu rendah karena manusia lebih mudah melindungi diri dari pengaruh suhu rendah disbanding suhu tinggi. ${ }^{4}$

ACGIH telah menentukan parameter untuk mengevaluasi iklim kerja panas dengan WBGT (Wet Bulb Globe Temperature) atau dengan ISBB (Indeks Suhu Basah dan Bola). Apabila tenaga kerja terpapar oleh panas melebihi Nilai Ambang Batas (NAB) yang diperkenankan maka dapat menimbulkan terjadinya penyakit akibat kerja dan kecelakaan kerja yang berdampak pada menurunnya produktivitas kerja. ${ }^{6}$ Iklim kerja panas dapat menyebabkan gangguan baik fisiologis maupun psikologis pada tenaga kerja. Respon fisiologis yang terjadi antara lain adalah vasodilatasi, peningkatan denyut nadi dan suhu tubuh inti. Respons fisiologis dapat diukur dengan peningkatan kehilangan keringat, denyut nadi dan suhu tubuh inti. Tenaga kerja yang terpapar oleh panas secara terus menerus dapat menyebabkan terjadinya heat rash, heat cramp, heat syncope, heat exhaustion, heat stroke, malaria, dehidrasi dan hipertermia. ${ }^{4}$

Penelitian di Australia pada buruh tambang bawah tanah dengan suhu lingkungan kerja $36,2^{\circ} \mathrm{C}$ menunjukkan bahwa $60 \%$ pekerja memulai shift bekerja dalam keadaan dehidrasi. Penelitian lain di Australia pada pekerja outdoor menunjukkan bahwa $79 \%$ pekerja mengalami dehidrasi. ${ }^{7}$ Di Indonesia Penelitian pada tenaga kerja bagian boiler di PT. Albasia Sejahtera Mandiri Semarang, menunjukkan bahwa terdapat pengaruh yang signifikan antara iklim kerja panas terhadap dehidrasi dengan nilai $p$ value sebesar 0,023 atau $\mathrm{p} \leq 0,05$. Berdasarkkan hal tersebut dapat diketahui bahwa iklim kerja panas mempengaruhi kondisi pekerja yaitu dehidrasi.

Industri keramik merupakan industri yang bergerak dalam industri pembuatan keramik hingga penjualan. Industri pembuatan keramik ini berada di wilayah Kabupaten Gresik. Membuat keramik memerlukan teknik-teknik 
yang khusus dan unik. Hal ini berkaitan dengan sifat tanah liat yang plastis dimana diperlukan ketrampilan tertentu dalam pengolahan maupun penanganannya. Membuat keramik berbeda dengan membuat kerajinan kayu, logam, maupun yang lainnya. Proses membuat keramik adalah rangkaian proses yang panjang yang didalamnya terdapat tahapan-tahapan. Salah satu tahapan yaitu adalah pembakaran.

Pembakaran dalam proses membat keramik sangat dibutuhkkan dalam memperkuat struktur keramik agar menjadi lebih keras. Pada proses pembakaran ini pula, paara pekerja selalu berhadapan dalam iklim kerja yang tidak nyaman yang dalam hal ini identik dengan iklim kerja panas. Iklim kerja panas sendri dapat mempengaruhi kondisi fisik dan mental pekerja. Dampak yang sering terjadi pada pekerja akibat iklim kerja panas yaitu kelelahan dan dehidrasi, tetapi masih banyak dampak lain dari iklim kerja panas yang diterima oleh pekerja. Latar belakang tersebut, menjadi dasar untuk meneliti tentang iklim kerja pada industri keramik. Tujuan dari penelitian ini adalah ingin mengetahui dan mengevaluasi iklim kerja pada industri keramik.

\section{METODOLOGI}

Lokasi penelitian ini dilakukan pada empat industri keramik yang terletak di wilayah Gresik, Jawa Timur. Jenis penelitian yang digunakan adalah penelitian deskriptif, dengan menggunakan rancangan cross sectional study. Populasi dalam penelitian ini adalah semua pekerja yang bekerja di bagian produksi mulai dari pengolahan bahan baku sampai packing yang berjumlah 39 orang. Sampel dalam penelitian ini adalah total populasi dengan pekerja yang bekerja dibagian produksi pada empat industri keramik.

Sumber data pada penelitian ini terbagi atas dua, yaitu: data primer yakni data yang diperoleh dari hasil wawancara pada Pekerja, dan data sekunder diperoleh dari data pengukuran lingkungan dengan menggunakan ISBB. Data yang telah dikumpulkan kemudian diolah secara manual dengan menggunakan program SPSS. Hasil pengolahan data disajikan dalam bentuk tabel dan narasi. Kerangka konseptual pada penelitian ini yaitu

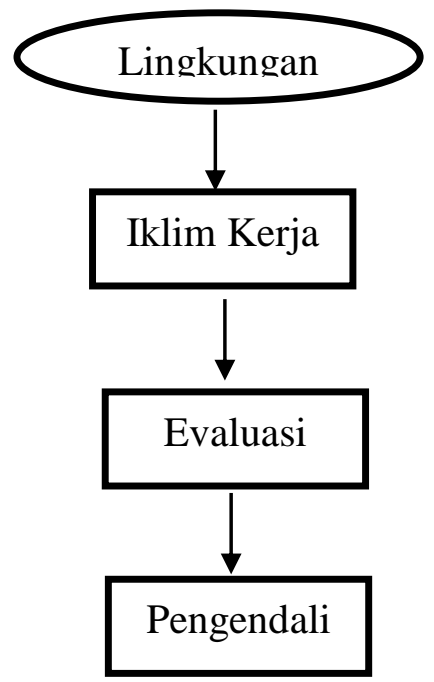

Gambar 1. Kerangka Konseptual Penelitian

\section{HASIL DAN PEMBAHASAN}

Berikut ini adalah hasil dan pembahasan dalam penelitian mengenai iklim kerja pada industri keramik.

\section{Hasil Pengukuran Iklim Kerja}

Iklim kerja merupakan kombinasi dari suhu kerja, kelembaban udara, kecepatan gerakan udara, dan suhu radiasi pada suatu tempat kerja. Iklim kerja yang tidak nyaman, tidak sesuai dengan syarat yang ditentukan dapat menurunkan kapasitas kerja yang berakibat menurunnya efisiensi dan produktifitas kerja.Suhu udara yang dianggap nikmat bagi orang Indonesia ialah berkisar $24^{\circ} \mathrm{C}-26^{\circ} \mathrm{C}$ dan selisih suhu didalam dan diluar tidak boleh lebihdari $5^{\circ}$ C.Batas kecepatan angin secara kasar yaitu 0,25 sampai $0,5 \mathrm{~m} / \mathrm{dtk}$.

Berikut ini adalah hasil pengukuran iklim kerja pada 4 perusahaan.

Tabel 1. Distribusi Hasil Pengukuran Iklim Kerja

\begin{tabular}{cccccc}
\hline \multirow{2}{*}{ No. } & \multirow{2}{*}{$\begin{array}{c}\text { Nama } \\
\text { lokasi }\end{array}$} & $\begin{array}{c}\text { Industri } \\
\text { A }\end{array}$ & $\begin{array}{c}\text { Industri } \\
\text { B }\end{array}$ & $\begin{array}{c}\text { Industri } \\
\text { C }\end{array}$ & $\begin{array}{c}\text { Industr } \\
\text { i D }\end{array}$ \\
\hline 1 & Titik 1 & 32,4 & 30,2 & 29,3 & 29,3 \\
\hline 2 & Titik 2 & 31,7 & 30,0 & 29,9 & 29,8 \\
\hline 3 & Titik 3 & 32,1 & 31,3 & 30,1 & 29,4 \\
\hline 4 & Titik 4 & 31,7 & 30,2 & 29,7 & 29,7
\end{tabular}

Hal 31 dari 35 


\begin{tabular}{cccccc}
\hline & & \multicolumn{4}{c}{ ISBB $\left({ }^{\circ} \mathrm{C}\right)$} \\
\cline { 3 - 6 } No. & \multirow{2}{*}{$\begin{array}{c}\text { Nama } \\
\text { lokasi }\end{array}$} & $\begin{array}{c}\text { Industri } \\
\mathrm{A}\end{array}$ & $\begin{array}{c}\text { Industri } \\
\text { B }\end{array}$ & $\begin{array}{c}\text { Industri } \\
\text { C }\end{array}$ & $\begin{array}{c}\text { Industr } \\
\text { i D }\end{array}$ \\
\hline 5 & Titik 5 & 30,6 & 31,8 & 30,0 & 29,9 \\
\hline 6 & Titik 6 & 31,9 & 32,0 & 29,9 & 30,3 \\
\hline 7 & Titik 7 & 30,7 & 32,1 & 31,1 & 29,4 \\
\hline 8 & Titik 8 & 30,4 & 33,1 & 32,3 & 30,2 \\
\hline 9 & Titik 9 & 32,3 & 31,0 & 31,0 & 30,4 \\
\hline 10 & Titik & 31,9 & 29,9 & 31,1 & 30,3 \\
& 10 & & & & \\
\hline
\end{tabular}

Data pada Tabel 1, diketahui bahwa hasil pengukuran iklim kerja pada 4 perusahaan yang dilakukan di masing-masing perusahaan dengan 10 titik mendapatkan hasil sebagian besar memiliki nilai ISBB $>30^{\circ} \mathrm{C}$. Hasil ini nantinya akan di analisis berdasarkan beban kerja dari pekerja, sehingga akan mendapatkan hasil kesesuaian iklim kerja pada pekerja.

\section{Gambaran Beban Kerja}

Pada industri keramik memiliki beberapa proses, membuat keramik memerlukan teknikteknik yang khusus dan unik. Membuat keramik berbeda dengan membuat kerajinan kayu, logam, maupun yang lainnya. Proses membuat keramik adalah rangkaian proses yang panjang yang didalamnya terdapat bebrapa tahapan.

Pengamatan yang telah dilakukan pada beban kerja pada industri keramik menunjukkan bahwa beban kerjanya tergolong sedang. Beban kerja sedang membutuhkan kalori 750 - 2000 kalori dalam setiap bekerja. Hal tersebut di sesuaikan dengan pengaturan waktu kerja yaitu $75 \%-100 \%$ dengan $25 \%$ waktu istirahat dari 8 jam kerja.

\section{Pembahasan}

\section{Analisis dan Evaluasi Iklim Kerja}

Iklim kerja adalah suatu kombinasi dari suhu kerja, kelembaban udara, kecepatan gerakan udara, dan suhu radiasi pada suatu tempat kerja. Iklim kerja yang tidak nyaman, tidak sesuai dengan syarat yang ditentukan dapat menurunkan kapasitas kerja yang berakibat menurunnya efisiensi dan produktifitas kerja.Suhu udara yang dianggap nikmat bagi orang Indonesia ialah berkisar $24^{\circ} \mathrm{C}-26^{\circ} \mathrm{C}$ dan selisih suhu didalam dan diluar tidak boleh lebihdari $5^{\circ} \mathrm{C}$. Batas kecepatan angin secara kasar yaitu 0,25 sampai $0,5 \mathrm{~m} / \mathrm{dtk}$.

Faktor fisik dalam lingkungan industri lebih banyak memberikan pengaruh terhadap lingkungan sekitarnya dan berakibat langsung terhadap tenaga kerja, salah satu diantaranya adalah iklim kerja yang mencakup suhu udara, kelembaban, kecepatan gerak udara dan panas radiasi. ${ }^{9}$

Proses produksi suatu industri sering menghasilkan suhu yang tinggi, yang diperoleh dari sumber panas tertentu seperti mesin produksi, dapur peleburan baja, dapur peleburan gelas, dapur pembakaran keramik, dan lain sebagainya. Oleh karena itu, umumnya di dalam industri sering kita jumpai adanya perbedaan suhu yang besar antara satu tempat dengan tempat yang lain, dan hal ini mengakibatkan terjadinya perbedaan panas yang besar pula. Panas mempunyai pengaruh terhadap kesehatan tubuh manusia. Dalam kaitan ini, ada satu hal yang sangat penting untuk diketahui dari pekerja yang bekerja di lingkungan tempat kerja yang panas yaitu tentang sumber panas. Salah satu sumber panas yaitu panas yang berasal dari mesin produksi. Semakin banyak mesin yang ada dalam proses produksi maka panas yang ditimbulkan juga akan semakin besar. ${ }^{10}$

Pengukuran Iklim kerja yang dilakukan pada 4 perusahaan pada industri keramik dengan 10 titik pengukuran di masing-masing perusahaan, diketahui memiliki hasil yaitu sebagian besar memiliki nilai ISBB $>30^{\circ} \mathrm{C}$. Pengamatan yang telah dilakukan pada industri keramik menunjukkan bahwa beban kerjanya tergolong sedang. Beban kerja sedang membutuhkan kalori 750 - 2000 kalori dalam setiap bekerja. Hal tersebut di sesuaikan dengan pengaturan waktu kerja yaitu $75 \%-100 \%$ dengan 25\% waktu istirahat dari 8 jam kerja. Pengaturan beban kerja ini di disesuaikan pada tingkat kegiatan dan kalori yang dihasilkan. Beban kerja sedang memiliki jenis pekerjaan seperti berdiri, mengangkat hingga mendorong dengan kebutuhan kalori 750-2000 kalori. ${ }^{4}$

Hasil analisis pada industri keramik A, diketahui 10 titik pengukuran memiliki hasil pengukuran seluruhnya $>30^{\circ} \mathrm{C}$ dengan waktu 
kerja 75\%-100\% dengan 25\% waktu istirahat (waktu kerja 6-7 jam dengan waktu istirahat 1-2 jam) . Jika dibandingkan dengan standar ISBB nilai tersebut berada di atas nilai ambang batas karena nilai ambang batas untuk beban kerja sedang dengan waktu kerja $75 \%-100 \%$ adalah $28^{\circ} \mathrm{C}$. Analisis iklim pada industri keramik A dapat di simpulkan bahwa hasil tersebut melebihi ambang batas yag telah di tentukan.

Hasil analisis lingkungan kerja memperoleh hasil yang sama pada industri keramik B, C dan D. Hasil analisis pada industri keramik 2 dengan 10 titik pengukuran memiliki hasil pengukuran yaitu 9 titik $>30{ }^{\circ} \mathrm{C}$ dan 1 titik berkisar di $29{ }^{\circ} \mathrm{C}$, industri keramik 3 dengan jumlah titik yang sama yaitu 10 titik pengukuran yang memiliki hasil pengukuran yaitu 6 titik $>$ $30{ }^{\circ} \mathrm{C}$ dan 4 titik beriksar di $29{ }^{\circ} \mathrm{C}$ dan yang terakhir yaitu industri keramik 4 dengan jumlah titik yang sama yaitu 10 titik pengukuran yang memiliki hasil pengukuran yaitu 4 titik $>30{ }^{\circ} \mathrm{C}$ dan 6 titik berkisar di $29{ }^{\circ} \mathrm{C}$.

Waktu kerja pada ke empat industri keramik tersebut yaitu menerapkan waktu kerja $75 \%-100 \%$ dengan $25 \%$ waktu istirahat (waktu kerja 6-7 jam dengan waktu istirahat 1-2 jam) . Jika dibandingkan dengan standar ISBB nilai tersebut berada di atas nilai ambang batas karena nilai ambang batas untuk beban kerja sedang dengan waktu kerja $75 \%-100 \%$ adalah $28^{\circ} \mathrm{C}$.

Tingkat indeks suhu bola basah di ke empat perusahaan yang di ukur dalam masingmasing 10 titik, di ketahui tidak satupun hasil memiliki nilai $28^{\circ} \mathrm{C}$. Nilai ambang batas dalam iklim kerja yaitu $28^{\circ} \mathrm{C}$. Hasil rata-rata ISBB dari ke empat perusahaan yaitu perusahaan $\mathrm{A}$ ratarata ISBB $31,57^{\circ} \mathrm{C}$, perusahaan $\mathrm{B}$ rata-rata ISBB $31,16^{\circ} \mathrm{C}$, perusahaan $\mathrm{C}$ rata-rata ISBB $30,44^{\circ} \mathrm{C}$, dan perusahaan D rata-rata ISBB $29,87^{\circ} \mathrm{C}$. Hal ini menunjukan bahwa berdasarkan hasil ratarata 10 titik dari ke empat perusahaan nilai ISBB hasil pengukuran lebih besar dari nilai NAB yang telah di tetapkan. Analisis iklim pada industri keramik A, B, C, dan D dapat di simpulkan bahwa hasil tersebut melebihi ambang batas yag telah di tentukan.

\section{Pengendalian Iklim Kerja Tinggi}

Pengendalian heat stress dan heat strain dipusatkan disekitar penyebab dari heat stress dan ketegangan physiology yang dihasilkan. Hal ini memerlukan :

1. Pengendalian secara umum

a. Training (pendidikan/latihan)

Yang dimaksud disini adalah pendidikan atau pelatihan bagi calon tenaga kerja sebelum ditempatkan yang dilaksanakan secara berkala (periodik).

b. Pengendalian tekanan panas melalui penerapan hygiene industri di perusahaan.

Yang dimakasud adalah tindakantindakan yang diambil oleh perorangan untuk mengurangi resiko penyakit yang disebabkan oleh panas. Termasuk pengendalian tekanan panas

melalui penerapan hygiene yaitu Pengandalian cairan, Aklimatisasi, Self determination, Diet, Makanan yang terlalu manis atau mengandung karbohidrat berlebihan tidak dianjurkan karena akan menahan cairan melalui ginjal atau keringat, Gaya hidup dan status kesehatan, Pakaian kerja.

2. Pengendalian secara khusus

Pengendalian secara khusus dapat dilaksanakan dengan 3 cara :

a. Pengendalian secara teknis

Cara ini mencakup mengurangi beban kerja, Menurunkan suhu udara, Menurunkan kelembaban udara, Menurunkan panas radiasi.

b. Pengendalian secara administratif

Adalah perubahan cara kerja yang dilakukan dalam upaya untuk membatasi resiko pemajanan.

c. Perlindungan perorangan

Adalah suatu cara pengendalian yang dilaksanakan perorangan (setiap pekerja). Untuk tekanan panas, perlindungan perorangan terutama berupa suatu pakaian pendingin, namun juga dapat termasuk pakaian yang dapat memantulkan panas radiasi yang tinggi dalam lingkungan tempat kerja panas. 


\section{SIMPULAN DAN SARAN}

Hasil penelitan mengenai evaluasi iklim kerja para pada industri keramik, maka dapat ditarik kesimpulan sebagai berikut:

Tingkat indeks suhu bola basah di ke empat perusahaan yang di ukur dalam masingmasing 10 titik, di ketahui tidak satupun hasil memiliki nilai $28^{\circ} \mathrm{C}$. Nilai ambang batas dalam iklim kerja yaitu $28^{\circ} \mathrm{C}$. Hasil rata-rata ISBB dari ke empat perusahaan yaitu perusahaan $A$ ratarata ISBB $31,57^{\circ} \mathrm{C}$, perusahaan $\mathrm{B}$ rata-rata ISBB $31,16 \mathrm{oC}$, perusahaan $\mathrm{C}$ rata-rata ISBB $30,44^{\circ} \mathrm{C}$, dan perusahaan $\mathrm{D}$ rata-rata ISBB $29,87^{\circ} \mathrm{C}$. Dibandingkan dengan beban kerja sedang dan Waktu kerja pada ke empat industri keramik tersebut yaitu menerapkan waktu kerja 75\%$100 \%$ dengan $25 \%$ waktu istirahat (waktu kerja 6-7 jam dengan waktu istirahat 1-2 jam). Hal ini menunjukan bahwa berdasarkan hasil rata-rata 10 titik dari ke empat perusahaan nilai ISBB hasil pengukuran lebih besar dari nilai NAB yang telah di tetapkan. Analisis iklim pada industri keramik A, B, C, dan D dapat di simpulkan bahwa hasil tersebut melebihi ambang batas yang telah di tentukan.

Saran yang diperlukan untuk perbaikan kedepannya yaitu perlu komitmen manajemen untuk menindak tegas dalam penyesuaian kondisi fisik lingkungan kerja. Departeman K3 tetap memberikan pengarahan kepada pekerja mengenai kenyamanan dalam bekerja dan batas waktu yang diberikan kepada pekerja sebelum melakukan pekerjaan, yang disesuaikan dengan iklim kerja dan lamanya bekerja.Meningkatkan pengawasan kepada pekerja selama melakukan pekerjaan, terutama pada pekerjaan yang berbahaya/berisiko tinggi mengakibatkan kecelakaan.

Perlunya pengendalian iklim kerja baik dalam lingkungannya maupun pekerjanya. Pengendalian tersebut yaitu Pengendalian secara umum seperti Training (pendidikan/latihan), Pengendalian tekanan panas melalui penerapan hygiene di perusahaan atau tempat kerja. Hingga Pengendalian secara khusus yaitu Mengurangi beban kerja, Menurunkan suhu udara, Menurunkan kelembaban udara, Menurunkan panas radiasi, Pengendalian secara administratif, Perlindungan perorangan. ${ }^{11}$

Meningkatkan sumber daya manusia pada staf SHE/pengawas dalam upaya penerapan Keselamatan dan Kesehatan Kerja di perusahaan terutama dalam penyehatan lingkungan kerja. Pada setiap tempat tersebut harus dilakukan controlling guna mengantisipasi adanya nilai iklim kerja yang melebihi NAB. Adapun controlling yang perlu dilakukan yaitu adanya pergantian shift kerja, pemberian gizi / kalori sesuai dengan aktivitas pekerja, serta pemberian ventilasi yang cukup supaya pertukaran udara di setiap bengkel tersebut maksimal. Di samping itu harus mengkalibrasi alat weather instrument/Thermocouple tersebut sesuai dengan standart operasional prosedur yaitu dua tahun sekali, dengan tujuan ketepatan pengukuran lebih akurat.

\section{UCAPAN TERIMA KASIH}

Terimakasih saya sampaikan kepada semua pihak yang telah membantu terlaksananya penelitian ini, dan prodi D-IV Keselamatan dan Kesehatan Kerja, Unusa yang telah banyak mendukung saya.

\section{REFERENSI}

1. Tarwaka, Keselamatan dan Kesehatan Kerja. Surakarta: Harapan Press, 2009.

2. Suma'mur, Higiene Perusahaan dan Kesehatan Kerja (HIPERKES). Jakarta: Sagung Seto, 2009.

3. Undang-Undang No. 13 Tahun 2003, Ketenagakerjaan. 2003.

4. Suma'mur, Higene Perusahaan dan Kesehatan Kerja (HIPERKES), 2nd ed. Jakarta: Sagung Seto, 2014.

5. M. Soeripto, Higiene Industri. Jakarta: Balai FK Universitas Indonesia, 2008.

6. American Conference Of Governmental Industrial Hygienists, Threshold Limit Values and Biological Exposure Indices. United States, 2015.

7. E. Hughes., $\mathrm{P}$ dan Ferret., "Introduction to Health and Safety at Work," Elsevier, 2009.

8. T. Trikasjono, Petunjuk Praktikum K3. Yogyakarta: STTN-Batam, 2015.

9. J. Ridley, Kesehatan dan Keselamatan Kerja. Jakarta: Erlangga, 2008.

10. Dainur, Ilmu Kesehatan Masyarakat "MateriMateri Pokok.” Jakarta: Widya Medika, 2012. 
ARTERI : Jurnal Ilmu Kesehatan

Vol. 1, No. 1, Nopember 2019, hlm. 29-35

11. G. of Alberta, "Workplace Health and Safety," 2011. [Online]. Available:

http://work.alberta.ca/documents/WHS-PUB-

SH013.pdf. [Accessed: 03-Oct-2019]. 